\title{
Erratum to: Human tissue thickness measurements from excised sleeve gastrectomy specimens
}

\author{
Logan Rawlins • Melissa P. Rawlins • \\ Donovan Teel II
}

Published online: 3 January 2014

(C) Springer Science+Business Media New York 2014

Erratum to: Surg Endosc 10.1007/s00464-013-3264-1

In Table 2 (Effect of gender on tissue thickness), in the line for Height change at the Fundus column, the current value reads $+0.26 \mathrm{~mm}$, but it should actually read $+0.15 \mathrm{~mm}$.

The online version of the original article can be found under doi:10.1007/s00464-013-3264-1.

L. Rawlins · D. Teel II

Wright State University, Dayton, OH, USA

L. Rawlins $(\varangle) \cdot$ D. Teel II

Miami Valley Hospital, Premier Bariatric \& Metabolic Surgery,

30 East Apple Street \#6258, Dayton, OH 45409, USA

e-mail: rawlinml@yahoo.com

M. P. Rawlins

Kettering Sycamore Bariatric Surgery, Dayton, OH, USA 